Марина Ђукић Мирзајанц ${ }^{1}$

Универзитет Сингидунум

Београд

Факултет за туристички

и хотелијерски менаџмент
УДК 371.3::811]:004

DOI 10.18485/zivjez.2016.36.1.12

Прегледни рад

\title{
НЕКИ ТЕОРИЈСКИ ПРИСТУПИ У НАСТАВИ СТРАНИХ ЈЕЗИКА ПОДРЖАНОЈ РАЧУНАРОМ
}

Рад је посвећен интеракционој хипотези, социокултурној и конструктивистичкој теорији. Сагледавају се њихови основни принципи, као и могућности примене у настави страних језика подржаној рачунаром. На примеру одређеног броја глотодидактичких истраживања у којима се испитују ефекти појединих технологија приказаће се предности и недостаци теоријских приступа којима се у датом раду бавимо. Једногласно мишљење стручњака јесте да су познавање и примена научно утемељених теорија кључ за побољшање квалитета наставе страних језика која се изводи традиционално или помоћу рачунара.

Кључне речи: интеракциона хипотеза, социокултурна теорија, конструктивистичка теорија, настава страних језика подржана рачунаром (CALL)

\section{Увод}

Учење представља сложен процес, а различите теорије усмеравају пажњу на различите делове тог процеса. Фактори учења наглашени у појединим теоријама могу бити игнорисани или квалификовани као секундарни у неким другим. Примера ради, док Пијажеова теорија примат даје мисаоним процесима, теорија Виготског у први план ставља социјалне аспекте учења. То ипак не значи да Пијаже негира улогу окружења и социјалних интеракција, нити да Виготски занемарује улогу појединца у учењу. Другим речима, свака теорија износи

1 marinadjukic@singidunum.ac.rs 
Марина Ђукић Мирзајанц

одређене идеје, претпоставке, концепте и решења. Зато је важно да наставник прати и познаје општеприхваћене и научно утемељене теорије јер ће му оне омогућити да изгради критички став према новинама, али и према свом сопственом раду. Следи преглед теорија које се најчешће користе у истраживањима посвећеним примени рачунара у настави страних језика (Л2).

\section{Интеракциона хипотеза}

Интеракциона хипотеза заснована је на хипотези језичког прилива (инпута) Стивена Крешена ${ }^{2}$, који је уочио да изложеност страном језику (у писаној или усменој форми) није довољна за његово учење/усвајање ${ }^{3}$, те се ученику мора пружити разумљив инпут, тј. лингвистичко окружење које је на мало вишем нивоу од онога којим он тренутно влада (Дурбаба 2011). Надовезујући се на ову идеју, заступници ${ }^{4}$ интеракционе хипотезе тврде да се инпут најбоље може обрадити кроз пpeговарање о значењу (енг. negotiation of meaning, нем. Aushandeln

2 Овај признати амерички лингвиста и глотодидактичар слови и за творца хипотезе усвајања и учења, хипотезе надзора (монитора), хипотезе природног редоследа и хипотезе афективног филтера (Дурбаба 2011: 78)

3 У глотодидактичкој литератури често се подвлачи разлика између усвајања и учења Л2. Крешен сматра да је усвајање Л2 процес сличан усвајању матерњег језика код деце (у школским условима једино могућ ако настава имитира „природне околности изложености страном језику“), док се учење заснива на памћењу правила и исправљању грешака (Дурбаба 2011: 79). Међутим, несвесно усвајање и свесно учење Л2 се међусобно не искључују. Многа језичка правила се честом употребом могу аутоматизовати и „пренети у домен усвојеног знања“ (ibid). Због тога се термин учење страног језика у овом раду односи и на учење и на усвајање.

4 Међу њима, најпре се истиче амерички глотодидактичар Мајкл Лонг (Michael Long), професор Универзитета Мериленд (енг. University of Maryland). Интеракциону хипотезу он децидно одбија да назове теоријом, будући да истраживања која се на њој заснивају сматра недовољно убедљивим (Леви и Стоквел 2006: 112). Уважавајући овај став, у раду користимо термин хипотеза. 
von Bedeutung), које настаје када ученици имају потешкоћа у разумевању непознатих елемената у поруци (Дурбаба 2011; Маркес-Шефер 2013). Како би разрешили пропусте у комуникацији, ученици се најчешће служе „распитивањем о недостајућим информацијама, провером разумевања, парафразирањем, исправкама, прецизирањем и сличним поступцима“ (Дурбаба 2011: 84). На тај начин они стварају модификовани инпут, који може прећи у интејк (Леви и Стоквел 2006: 113).

Преговарање о значењу могуће је остварити и у интеракцији рачунара и ученика (Шапел 2003). Дату тврдњу поткрепљују резултати експерименталног истраживања које је Маја Андријевић (2007) спровела на Филолошком факултету Универзитета у Београду са циљем утврђивања значаја електронских глоса ${ }^{6}$ у опажању и разумевању инпута. У истраживању су учествовали студенти Катедре за иберијске студије. Контролна група добила је текстове на папиру, без икаквих објашњења непознатих речи, али са могућношћу коришћења једнојезичних и двојезичних речника. Експериментална група је добила исте текстове, али поткрепљене разноврсним објашњењима у виду електронских глоса. ${ }^{7}$ Студенти експерименталне групе су приступали текстовима путем веб-сајта направљеног за потребе истраживања. Обе групе су имале задатак да прочитају текстове и да након тога одговоре на питања у вези са прочитаним текстом. Сваки текст је носио одређен број бодова. Анализа добијених резултата, као што се и очекивало, показала је да су студенти експерименталне групе, захваљујући модификованом инпуту у виду електронских глоса, имали више

5 Интејк (енг. intake) представља онај део инпута који ученик заиста процесуира и усваја и који, уједно, постаје део његове компетенције (Завишин 2013: 340).

6 Глоса (грч. glôssa) представља „превод, тумачење или кратки коментар непознате речи или израза у старом рукопису“ (Клајн и Шипка 2006: 297).

7 У сврху разумевања речи и структура које су захтевале модификовани инпут, ауторка је користила слике, комбинацију објашњења и слике, стрип, кратке видео- и аудио-записе, објашњења у виду сопствених примера, граматичка објашњења у виду табеларних приказа, историјске, културолошке и литерарне референце. 
Марина Ђукић Мирзајанц

бодова у односу на контролну групу, те да су давали садржински потпуније одговоре и брже извршавали своје задатке. ${ }^{8}$ Ипак, Карол Шапел ${ }^{9}$ (2003: 85) истиче да је у интеракцији рачунара и ученика (у којој захтев за откривање значења никад није вербалан, већ се састоји од притиска на миш и бирања различитих опција) модификовани инпут у виду електронских глоса увек обилнији и другачији од оног у интеракцији наставника и ученика (у којој, примера ради, никада нема транскрипције, већ се прибегава успоравању говора или понављању).

Интеракциона хипотеза, као теоријски оквир, претежно се користи у истраживањима која се баве комуникацијом посредованом рачунаром (Леви и Стоквел 2006). У таквим истраживањима најчешће се примењује Варонисов и Гасов модел, који се показао као веома погодан за описивање и разумевање интеракционог преговарања (Јангвас 2010; Јеонг 2011; Маркес-Шефер 2013; Фернандез-Гарсија, Мартинез-Арбелаиз 2002). Према њиховом моделу (Варонис и Гас 1985: 74), поступак преговарања садржи два корака: иницирање (енг. trigger, нем. Auslöser) и разрешење (енг. resolution, нем. Auflösung) (в. Табелу 1). Исказ или део исказа говорника који саговорник не разуме Варонис и Гас називају иницирањем. Наредни корак је разрешење и састоји се од два елемента: индикатора ${ }^{10}$ (енг.

8 Поставља се питање да ли би студенти контролне групе подједнако успешно или успешније решавали задатке да су модификовани инпут осим из речника, добијали и од наставника. Имајући ово у виду, било би интересантно истражити како модификовани инпут, добијен од стране наставника и рачунара, утиче на успешност решавања истих задатака, те да ли и у том случају електронске глосе доприносе бољем памћењу обележених речи у текстовима.

9 Карол Шапел (Carol Chapelle), једна од најутицајнијих међу глотодидактичарима у области примене рачунара у учењу и настави Л2, професорка је на Државном универзитету Ајове.

10 Варонис и Гас (1985: 75) идентификовали су неколико врста индикатора. То су: ехо (у ову врсту спадају понављање непознатог лексичког елемента, прозодијски паралингвистички знаци као што је интонација, паралингвистички знаци попут гестикулације, израза лица, покрета главе и очију); експлицитна изјава да саговорник није разумео говорника; изостајање вербалног одговора саговорника, као и неодговарајући одговор саговорника. 
indicator, нем. Hinweis), којим саговорник говорнику ставља до знања да није разумео исказ до краја, и одговора (енг. response, нем. Antwort), којим говорник потврђује захтев за појашњење (у најчешће одговоре спадају понављање, проширење израза, парафразирање, потврђивање или скраћивање израза). Уколико се преговарање обави успешно, саговорник који је указао на неразумевање завршава процес преговарања уобичајеним изразима као што су „да, хвала“, „разумем“ или „јасно“, чиме потврђује да је примио понуђену помоћ.

\begin{tabular}{ll}
\hline \hline Phasen einer Sequenz & Verständnisfrage \\
\hline trigger/Auslöser & $(09: 12: 53)$ Tutorin A: Hast du schon eine Zu- \\
& lassung von der Universität? \\
& $(09: 13: 04)$ Joana: ja \\
& $(09: 13: 11)$ Tutorin A: Dann ist es toll \\
& $(09: 13: 41)$ Tutorin A: Warum hast du Muen- \\
& ster zum Studium gewählt? \\
\hline indicator/Hinweis & $(09: 13: 42)$ Joana: was bedutung toll? \\
response/Antwort & $(09: 14: 07)$ Tutorin A: Toll bedeutet in diesem \\
& Satz "schoen" \\
& $(09: 14: 17)$ Tutorin A: Das ist sehr gut \\
& $(09: 14: 25)$ Tutorin A: Ich freue mich für dich \\
\hline reaction/Reaktion & $(09: 14: 37)$ Joana: ja, danke \\
\hline \hline
\end{tabular}

Табела 1. Пример преговарања у ћаскаоници JETZT Deutsch lernen-

Chat (Маркес-Шефер 2013: 124)

Примењујући Варонисов и Гасов модел, Фернандез-Гарсија и Мартинез-Арбелаиз (2002) изучавали су преговарање о значењу између говорника Л2 у синхроним дискусијама ученика шпанског језика. Они су установили да језик ћаскаонице не подстиче у великој мери преговарање о значењу, као што се и очекивало. Тамо где ипак до преговарања дође, оно се углавном односи на значење лексичких елемената. Већина прекида у комуникацији успешно је превазиђена превођењем нејасне речи на Л1. Испитаници су показали већу склоност ка коришћењу одређених врста индикатора и одговора. Употреба писаног медија могла би да објасни преовлађујуће присуство експлицитних 
Марина Ђукић Мирзајанц

начина изражавања неразумевања, као и ретко присуство или одсуство других врста индикатора. У истраживању су идентификована само два примера еха, а да притом није дат ниједан пример неодговарајућег одговора. Овај налаз аутори објашњавају аргументом да у усменој комуникацији постоји притисак да се одржи ток разговора, што саговорника може подстаћи да употреби погрешан одговор. Дата врста притиска у писаној комуникацији не постоји. Код испитаника нису забележене врсте одговора које Варонис и Гас наводе у свом моделу, са изузетком једног примера понављања у виду самоисправке.

До занимљивих резултата дошла је и Габријела Маркес-Шефер (2013), која је у оквиру пројекта Гетеовог института JETZT Deutsch lernen ${ }^{11}$ истраживала могућности и ограничења учења немачког језика у дидактизованом простору за ћаскање, као и поступање наставника - ментора у случају грешака или лингвистичких и културолошких питања ученика. Анализом су обухваћени разговори 40 испитаника, вођени у присуству и одсуству ментора. У обрађеном корпусу (укупно 80 интеракција) ауторка је идентификовала 210 примера преговарања, од којих 62\% чине интеракције ученика и ментора, а 38\% примери међусобне интеракције ученика. Овај по-

11 Пројекат JETZT Deutsch lernen осмишљен је 1996. године на Јустус-Либих универзитету у Гисену (нем. Justus-Liebig-Universität Gießen) на иницијативу Гетеовог института у сарадњи са онлајн омладинским часописом jetzt.de, издаваним под окриљем дневног листа Süddeutsche Zeitung, а његову реализацију пратила је и истраживала научна заједница (Mapкес-Шефер 2013: 103). Пројекат је настао са идејом да напредним ученицима немачког језика и наставницима из целога света бесплатно пружи мултимедијалан амбијент за учење у виртуелном простору и стави им на располагање наставни материјал, аутентичне текстове из поменутог часописа, дидактизоване видео прилоге, активности и савете за успешну наставу немачког језика као страног. Свим заинтересованим странама били су доступни разноврсни задаци (затвореног, полуотвореног и отвореног типа) у циљу подстицања развоја разумевања говора и писаног текста, кооперативног и креативног писања, слободне комуникације и медијске компетенције (ibidem). Пројекат је завршен у марту 2014. године и преобликован у нови портал Гетеовог института Deutsch für dich, који, поред електронског ћаскања, омогућава и коментарисање различитих тема у оквиру дискусионих група. 
датак указује да присуство ментора стимулише преговарање о значењу. Анализирајући 54 питања испитаника о самом језику (нем. sprachbezogene Fragen), Маркес-Шефер је дошла до закључка да 74,2\% примера спада у коректуру грешака, а преосталих 25,8\% чине питања за проверу разумевања лингвистичких елемената у поруци.

Из наведеног се може закључити да и ментори и учесници велики значај придају исправљању грешака. Наглашено је да су ученици постављали више питања о значењу речи и израза у немачком језику, а мање о граматици. Анализом података ауторка је установила да се питања о језику, статистички посматрано, појављују у сваком разговору вођеном уз присуство ментора. У међусобним разговорима ученика то се ређе догађало - питање о језику појављивало се у свакој четвртој дискусији. Овај налаз Маркес-Шефер образлаже чињеницом да је већина испитаника свесна да је когнитивни напредак једино могућ у сарадњи са ментором (ibidem: 300).

Интеракциону хипотезу нису заобишле критичке анализе у којима се истиче да разумљив инпут и стварање прилика за интеракцију нису довољни услови за језичко напредовање (Дурбаба 2011). Активна употреба језика (Свејн 2000) и усмеравање пажње на граматичке садржаје, како у инпуту, тако и у аутпуту (Ли 2008), такође су потребни за успешно учење Л2.

Теорије изложене у наредним поглављима учење Л2 посматрају првенствено као социјални чин, за разлику од интеракционе хипотезе која га види као постигнуће појединца који „релативно самостално користи неке унутрашње механизме да би истражио променљив спектар нових информација понуђених у интерактивном окружењу“ (Мичел и Мајлс 2004: 122).

\section{Социокултурна теорија}

Социокултурна теорија почива на поставкама руског психолога Лава Виготског (Ганем-Гутиерез 2006, 2008; Лантолф 2000). Његова указивања на ефекат социјалних интеракција на ментални развој детета умногоме су обликовала дана- 
шњу педагошку теорију и праксу. У књизи Мишљење и говор Виготски (1983: 188) износи тврдњу да „у сарадњи, уз нечије руковођење и уз нечију помоћ дете увек може урадити више и решити теже задатке него самостално“. Оно што дете може самостално да научи Виготски назива „зоном актуелног развоја“, док под „зоном наредног развоја“ подразумева оно што дете може научити у интеракцији са наставником или компетентнијим вршњаком. Ученици, према овом приступу феномену стицања знања, највећу корист имају од задатака који су изнад њихове тренутне компетенције, а улога наставника је да им помогне да превазиђу јаз између онога што умеју и онога што могу да ураде уз помоћ других (Леви и Стоквел 2006: 116). Кроз сарадњу са способнијим партнером ученик формира и постепено интернализује нове когнитивне способности. Стога се учење прво одвија на интерпсихолошком (социјалном), а затим на интрапсихолошком (индивидуалном) плану, што је Виготски формулисао „општим генетичким законом културног развоја“ (Виготски 1996: 114).

Поред разраде концепта „зоне наредног развоја“, социокултурна теорија уводи и концепт медијације. За Виготског (1983) сва људска делатност изводи се помоћу неког средства. Према његовим речима, посредовање се може вршити употребом оруђа (нпр. везивањем чвора којем је човек у древним временима прибегавао као поузданом средству памћења), затим интеракцијом са другим особама или употребом симбола. Појава језика, као симболичког средства, кључна је за развој виших менталних функција. Култура, као производ и истовремено творац одређеног лингвистичког система, у непрестаној је интеракцији са појединцима који у тој култури живе. Разматрајући ове идеје Виготског, Јасмина Ђорђевић (2013: 108-109) пише: „Језик и култура нису два отуђена система, већ јединствени оквир без којег појединац не би могао да постоји као свесно биће, јер га културно порекло дефинише као припадника одређене групе, а језик му омогућава да се као припадник те групе изрази, дакле афирмише.“ Отуд „појединац учењем језика заправо усваја и културу“. 
Џејмс Лантолф (James Lantolf), најутицајнији представник социокултурног приступа у глотодидактици, учење Л2 такође види као процес медијације. Он је медијацију у учионици поделио у три категорије: 1. социјална медијација (енг. social mediation), која се реализује комуникацијом ученика и наставника, као и самих ученика међусобно; 2. самомедијација (енг. self-mediation) - реализује се самоуправним говором (енг. private speech) ${ }^{12}$ којем ученик најчешће прибегава када жели да побољша сналажење у извођењу задатка; 3. медијација артефакта (енг. artifact mediation), која се обавља помоћу артефаката као што су задаци, портфолио, технологије (Лантолф 2000).

Микрогенеза је још један веома важан концепт у теорији Виготског. Она се често примењује у истраживањима која треба да одговоре на питања о учењу језика у току интеракције и о врсти дијалога која доводи до развоја језичке компетенције (Леви и Стоквел 2006). Развој и порекло виших менталних функција, као што су вољна пажња, логичко памћење, мишљење и сложене емоције, Виготски анализира путем четири генетичке области (Ганем-Гутиерез 2008: 122): филогенетску (истражује како се човек развијао различито од животиња, захваљујући раду и употреби оруђа и знакова), социокултуролошку (бави се питањем које културне творевине имају улогу медијатора и утичу на психичке делатности), онтогенетску (изучава како се средства медијације интегришу у когнитивну активност током процеса индивидуалног развоја) и микрогенетску (фокусира се на очигледне примере учења који се дешавају током интерпсихолошке активности и који се могу „ограничити на свега неколико секунди или чак на делове секунди“).

Микрогенеза, коју Џејмс Верч (James Wertsch) описује као „веома краткотрајно лонгитудинално истраживање“, истовре-

12 Охта (према Елис 2003: 180) дефинише самоуправни говор као „аудитивни говор неприлагођен за примаоца“, који може да има различите видове испољавања, као што су имитација, одговор ученика на наставниково питање упућено другом ученику и ментално понављање. 
Марина Ђукић Мирзајанц

мено се односи на метод и предмет проучавања порекла и историје одређеног догађаја (Ганем-Гутиерез 2008: 123). Она омогућава истраживачу да проучи и разуме „локални, контекстуализовани процес учења [који] се понекад може визуелно пратити док траје разговор између стручњака и почетника" (Мичел и Мајлс 2004: 198). Међутим, нису све врсте разговора подједнако подесне за когнитивни и лингвистички развој. Бројни истраживачи су установили да једино колаборативни дијалог може довести до заједничке конструкције лингвистичког знања путем процеса интернализације, тј. унутрашње реконструкције (ibidem). Према наводима Мерил Свејн (2000: 97), колаборативни дијалог „представља процес у коме се употреба и учење језика одвијају истовремено. У овом процесу употреба језика посредује у учењу језика. Ради се о активности која је у исто време и когнитивне и друштвене природе." Како Свејн наводи, ученици не учествују у колаборативном дијалогу не само зато што не разумеју саговорнике и морају да преговарају о значењу, већ и зато што примећују одређени лингвистички проблем за који покушавају да пронађу решење.

Теорију Виготског је у свом истраживачком раду применила Ганем-Гутиерез $(2006,2008)$. Она је проучавала колаборативне активности које је користила у настави шпанског као страног језика на нивоу А2 (Ганем-Гутиерез 2006). Ганем-Гутиерез је поставила три истраживачка питања. Прво питање истражује у којој мери различити задаци подстичу колаборативни рад у учионици. Како би одговорила на њега, Ганем-Гутиерез је извршила анализу транскрибованих података користећи технике идентификовања и бројања колаборативних епизода у сваком понуђеном задатку. Друго истраживачко питање посвећено је микрогенези и идентификовању примера микрогенетичких активности током решавања задатка. У ту сврху ауторка се бавила истраживањем лингвистичких ${ }^{13}$ и микрогенетичких ${ }^{14}$ епизода.

13 Свејн дефинише лингвистичку епизоду (енг. language related episode) као „било који део дијалога у коме ученици разговарају о језику који стварају, преиспитују сопствену употребу или исправљају туђе или сопствене неправилности у употреби језика“ (према Ганем-Гутиерез 2006: 240).

14 Леви и Стоквел (2006: 117) интерпретирају микрогенетичку епизоду (енг. microgenetic episode) као део дијалога „у коме је могуће надгледати процес учења језика“. 
И, најзад, последњим питањем истражује се однос између микрогенезе и специфичности рачунара као медијатора. У жељи да дође до одговора Ганем-Гутиерезје врши поређење задатака на папиру и задатака у електронској форми ${ }^{15}$ са циљем да преиспита улогу рачунара у колаборативном дијалогу. Рачунар је одиграо значајну улогу једино у припремним задацима (као што су превод, попуњавање празнина или повезивање измешаних реченица), чији је циљ да код ученика учврсте тек формирано знање из области граматике, непходно за решавање главног задатка. Захваљујући тренутној повратној информацији, ученици нису морали да чекају наставника који би проверио тачност њиховог рада и дао накнадне смернице и вежбања, што је био случај код ученика који су исти задатак радили у штампаној форми. Међутим, у реконструкционим задацима и задацима писаног изражавања већи проценат лингвистичких и микрогенетичких епизода забележен је у разговору ученика који су користили штампане материјале. Стога Ганем-Гутиерез закључује да приликом избора задатка наставник мора истовремено да обрати пажњу на њихову врсту и утицај који на интеракцију врши медиј уз чију помоћ се задатак израђује (ibidem: 249).

На основу изложеног могуће је доћи до закључка да је социокултурна теорија изнедрила значајан број нових концепата. За представнике овог теоријског усмерења делотворна је само она интеракција у којој постоји асиметрија когнитивних компетенција партнера. Као идеалан партнер најчешће се предлаже наставник, будући да је он носилац сазнања и вредности културе. У домену наставе подржане рачунаром социокултурна теорија највише се примењује за истраживање кооперативног ${ }^{16}$ и колаборативног ${ }^{17}$ учења зато што анализира међусобну пове-

15 Ауторка је за израду електронских задатака користила ауторски програм Hot Potatoes.

16 Код кооперативног облика учења и наставе наставник има пуну контролу над активностима на часу. Он пажљиво бира наставни материјал, планира и структурира задатке, са циљем да ученике постепено осамостали и оспособи за решавање пројектног задатка (Ераковић 2013: 128).

17 Код колаборативног облика учења и наставе наставник има веома ограничену могућност планирања. Процес одлучивања, динамика рада и избор наставних тема и релевантног материјала прелази у 
Марина Ђукић Мирзајанц

заност учесника у наставном процесу и подржава концепт наставе у којем процес медијације заузима главну улогу (Леви и Стоквел 2006: 118).

\section{Конструктивистичка теорија}

Највећим делом као реакција на ограничења научног реализма (Стојнов 2005), крајем седамдесетих година 20. века настаје нови филозофски правац који ће имати великог утицаја на методолошке оријентације у настави Л2 (Дурбаба 2011). Реч је о конструктивистичкој теорији, која се темељи на веровању да сваки појединац субјективно сагледава, разуме и конструише свет око себе (ibidem: 69). Упркос чињеници да су се током времена развили различити конструктивистички правци ${ }^{18}$, Ришоф и Волф (1999: 32) износе неколико основних полазишта ове теорије:

- Учење је динамичан процес. Ученици активно конструишу своје знање.

- Учење је аутономан процес. Сваки ученик је одговоран за сопствено учење.

- Учење је експерименталан процес. Ученици истражују и повезују ново знање са раније обрађиваним садржајима.

- Учење се дешава у социјалном контексту, а интеракција између ученика представља његов незаобилазни део.

- Учење је процес који подразумева разноврстан наставни материјал и подстицајну радну средину, ону која подржава учење путем открића.

Конструктивистичка гледишта присутна су и у радовима Жана Пијажеа, Лава Виготског и Џерома Брунера. Пијажеов конструктивизам заснован је на његовом схватању когнитивног развоја детета (Љубојевић 2013). По његовом мишљењу,

руке ученика, стога у центру наставног процеса нису ни наставник ни ученик, већ учење (Ераковић 2013: 131).

18 О различитим конструктивистичким усмерењима писали су Стојнов (2005) и Милутиновић (2011). 
„разумети просто значи открити или реконструисати поновним откривањем“ (Piaget 1977: 2). Ученик се посматра као активан појединац који нова знања и искуства креира у процесима асимилације („примен[е] већ стечених концепата сазнања на неки нови предмет“) и акомодације („промен[е] већ стечених концепата сазнања због немогућности да се усвоји нови“) (Дурбаба 2011: 68). Због давања предности интрапсихолошким когнитивним процесима у конструисању знања, Пијажеа сматрају зачетником тзв. индивидуалног конструктивизма (Стојнов 2005). У најзначајније педагошке ефекте Пијажеове теорије на наставу Л2 убрајају се:

- инсистирање на откривању, трансформацији, разумевању и стварању структура (граматичких и функционалних);

- развијање унутрашње мотивације;

- убрзавање развоја интелигенције помоћу увођења когнитивих конфликата код субјеката, јер су изложени различитим језичким системима и културама;

- развијање когнитивних схема које утичу на разумевање градива (Љубојевић 2013: 31).

Припадници тзв. социјалног конструктивизма најчешће се позивају на социокултурну теорију Лава Виготског. У оквиру овог теоријског усмерења учење се дефинише као ко-конструкција знања, тј. као резултат заједничке активности партнера у „зони наредног развоја“ (Милутиновић 2011; Пешикан 2010). То значи да едукативном искуству не доприноси искључиво наставник већ и сами ученици, и то активном међусобном сарадњом. Концепт „зоне наредног развоја“ инспирисао је Џерома Брунера (Jérôme Bruner) да уведе појам „грађевинска скела“ (енг. scaffolding). Дата метафора у глотодидактичкој употреби односи се на „свак[у] врст[у] помоћи коју ученику пружа наставник или нека друга особа из његовог окружења у циљу олакшавања задатка за који се може претпоставити да ће ученику бити претежак и да га неће моћи обавити“ (Дурбаба 2011: 40). У класичне примере пружања подршке Вуд, Брунер и Рос убрајају ситуације када наставник: (1) заинтересује ученика за задатак, (2) поједностави задатак; (3) мотивише ученика 
Марина Ђукић Мирзајанц

да обави задатак до краја; (4) означи критичке тачке и неусаглашености између оног што је ученик изговорио и идеалног решења; (5) контролише фрустрације током решавања задатка; (6) презентује идеално решење (Елис 2003: 184).

Брунерова теза о изградњи потпоре за овладавање језичким знањима и вештинама представља основу колаборативног модела учења за који се социјални конструктивизам залаже. Колаборативно учење Хара дефинише као „заједнички рад ради постизања заједничког циља и дељења знања“ (Радић-Бојанић 2012: 24). Истраживање Бориславе Ераковић (2013: 131) показало је да студенти укључени у колаборативне задатке превођења од самог почетка преузимају одговорност за стицање знања, па тако самостално врше селекцију информација, расподељују обавезе међу собом, планирају рад и постижу договор путем отвореног дијалога, како би задатак завршили у предвиђеном року. Студенти-сарадници се узајамно оснажују, те као група постижу оно што не могу да остваре као појединици. Након упознавања студената са задатком и давања упутства, наставник је присутан као неко ко прати, слуша и подстиче колаборативни дијалог, а у интеракцији учествује тек онда када студенти експлицитно затраже помоћ (ibidem) или када не успевају да нађу излаз из конфликтне ситуације (Радић-Бојанић 2012). Виртуелна колаборација ученика, како наводи Радић-Бојанић (ibidem), најчешће резултира одређеним продуктом (пројектом, презентацијом, извештајем или саставом на којем ради двоје или више ученика).

Осим идеје о изградњи потпоре за овладавање знањима, заслуга Брунерове теорије огледа се у тврдњи да настава заснована на постављању проблема и откривању правила доводи до ефикаснијег учења (Љубојевић 2013). Граматичка грађа у уџбеницима Л2 најчешће се обрађује кроз примере помоћу којих се најбоље истичу функција граматичке појаве, њена употреба и значење. Извођење правила на основу понуђених примера (тзв. индуктивни приступ) подстиче вештине препознавања образаца и решавање проблема, што одговара ученицима који воле ову врсту изазова. У настави на даљину то се 
може постићи употребом софтвера за израду конкорданције (енг. concordance software) ${ }^{19}$, тј. листе реченица у којима се тражени језички елемент (предлог, везник, реч, фраза) појављује у различитим контекстима (Гринер и Хасерт 2000: 44). Реч је, дакле, о програмима који у одабраном корпусу текстова претражују одређену реч или комбинације речи.

С друге стране, има ученика којима индуктивни приступ не одговара због аналитичког стила учења или претходног језичког искуства, те им експлицитна објашњења правила омогућују боље и лакше савладавање Л2. Такви ученици желе да предочено правило увежбају пре него што га употребе у комуникативним активностима (Леви и Стоквел 2006). У томе им могу помоћи граматичка вежбања која последњих година за потребе наставе састављају наставници користећи ауторске програме као што је Hot Potatoes (Ђукић Мирзајанц 2013).

Сумирајући наведено можемо закључити да конструктивизам критикује слику пасивног ученика који једноставно меморише садржаје изложене од стране наставника. Он види ученика као „аутономног градитеља, проценитеља, стратега, контролора сопственог знања“, а наставника као „водитеља, мотиватора, су-истраживача“ (Ераковић 2013: 127). Између актера у настави не постоји подређени, већ сараднички однос. Највише времена наставник посвећује осмишљавању комуникативних активности које ученике мотивишу и подстичу на истраживање, дискусију, сарадњу и преговарање. Одговорност за учење постепено се са наставника преноси на ученика. У контексту наставе подржане рачунаром ученици активно конструишу знање, најчешће кроз колаборативне задатке у чијем решавању им помаже технологија (Леви и Стоквел 2006). Гојков (2002: 45), међутим, упозорава да „конструктивистички поступци не развијају код свих ученика активне, конструк-

19 Примери за такву врсту софтвера су: MicroConcord, MonoConc, Wordsmith, PhraseContext, Simple Concordance Program. Програми за израду конкорданције могу бити монолингвални (ученик искључиво истражује језичку грађу Л2) и билингвални (ученик истовремено упоређује примере на Л1 и Л2) (Гринер и Хасерт 2000). 
Марина Ђукић Мирзајанц

тивне, самоорганизационе процесе у току учења“, те, стога, предлаже тзв. „умерени конструктивизам“, тј. „коегзистенцију између конструкције и инструкције“. Та коегзистенција се остварује постепеним смањивањем непосредне инструкције, паралелно са све развијенијом аутономијом ученика у овладавању знањем.

\section{Закључак}

За представнике социокултурне теорије, чији је предмет теоријског уопштавања и анализе међусобна повезаност учесника у наставном процесу, делотворна је само она интеракција у којој постоји асиметрија у погледу когнитивних компетенција партнера. Као идеалан партнер најчешће се предлаже наставник, с обзиром на то да је он носилац сазнања и вредности културе. Треба подсетити и да се у средишту интересовања конструктивистичке теорије налазе индивидуалне и друштвене конструкције стварности, те ова теорија критикује слику пасивног ученика који меморише садржаје изложене од стране наставника. Између актера у настави не постоји подређени, већ сараднички однос, а одговорност за учење постепено се са наставника преноси на ученика.

Имајући све навдено у виду, може се закључити да ниједна од поменутих теорија није разрешила све проблеме у учењу Л2. Према томе, како Оливера Дурбаба (2011: 70) сугерише, сваку теорију треба посматрати као „идејни оквир у којем ће се обављати истраживања, постављати нова питања и трагати за одговорима“. Предлози за успешну наставну праксу су бројни и ниједан од њих не би требало унапред одбацити. Разноликост теоријских приступа помаже наставнику да изгради метод који ће бити најделотворнији за његове ученике. Њихов утицај се може манифестовати у начину на који наставник поступа са грешкама својих ученика или како осмишљава наставне активности. Ипак, оно што се на основу лингводидактичке теорије и праксе може неоспорно закључити јесте да познавање 
и примена научно утемељених теорија представљају кључ за побољшање квалитета наставе страних језика.

\section{ЛИТЕРАТУРА}

Андријевић 2007: Андријевић, М. (2007). Улога хипертекста у разумевању читања: провера хипотезе о значају опажања у усвајању језичког материјала у Л2. Необјављени магистарски рад. Београд: Филолошки факултет Универзитета у Београду.

Варонис иГас 1985: Varonis, Е. M. \& S. Gass. (1985). Non-native/non-native conversations: A model for negotiation of meaning, Applied Linguistics, VI, 1, 71-90.

Виготски 1983: Vigotski, L. (1983). Mišljenje i govor. Beograd: Nolit.

Виготски 1996: Vigotski, L. (1996). Problemi razvoja psihe. Beograd: Zavod za udžbenike i nastavna sredstva.

Ганем-Гутиерез 2006: Gánem-Gutiérrez, G. A. (2006). Sociocultural theory and its application to CALL: A study of the computer and its relevance as a mediational tool in the process of collaborative activity, ReCALL, XVIII, 2, 230-251.

Ганем-Гутиерез 2008: Gánem-Gutiérrez, G. A. (2008). Microgenesis, method and object: a study of collaborative activity in a Spanish as a foreign language classroom, Applied Linguistics, XXIX, 1, 120-148.

Гојков 2002: Gojkov, G. (2002). Od konstruktivizma do alosteričnog modela učenja. Zbornik Katedre za pedagogiju, 17. Novi Sad: Filozofski fakultet, 30-41.

Гринер и Хасерт 2000: Grüner, М. \& T. Hassert. (2000). Computer im Deutschunterricht, Fernstudieneinheit 14, Berlin/München: Langenscheidt.

Дурбаба 2011: Дурбаба, О. (2011). Теорија и пракса учења и наставе страних језика. Београд: Завод за уџбенике.

Ђорђевић 2013: Đorđević, J. (2013). Integracija elemenata maternje kulture i stranog jezika: korak ka podizanju svesti o sopstvenoj multikulturalnosti u savremenom srpskom društvu. U: Živković, M. et al. (prir.) Multikulturalnost i savremeno društvo. Novi Sad: Visoka škola „Pravne i poslovne akademske studije dr Lazar Vrkatić”, 103-116.

Ђукић Мирзајанц 2013: Ђукић Mirzayantz, M. (2013). Резултати примене ауторског програма Hot Potatoes у настави немачког језика као страног, Иновације у настави, XXVI, 4, 79-85. 
Елис 2003: Ellis, R. (2003). Task-based language learning and teaching. Oxford: Oxford University Press.

Ераковић 2013: Eraković, B. (2013). Kompetencije prevodilaca sa engleskog jezika (uloga kooperativnog i kolaborativnog oblika nastave). Neobjavljena doktorska disertacija. Novi Sad: Filozofski fakultet Univerziteta u Novom Sadu.

Завишин 2013: Zavišin, K. (2013). Teorijske osnove i kritička analiza CLIL nastave na italijanskom i srpskom jeziku u srednjoj školi u Srbiji. Neobjavljena doktorska disertacija. Beograd: Filološki fakultet Univerziteta u Beogradu.

Јангвас 2010: Yanguas, I. (2010). Oral computer-mediated interaction between L2 learners: It's about time!, Language Learning \& Technology, XIV, 3,72-93.

Јеонг 2011: Jeong, N. S. (2011). The effects of task type and group structure on meaning negotiation in synchronous computer-mediated communication. U: Plonsky, L. \& M. Schierloh (prir.) Selected proceedings of the 2009 second language research forum. Somerville: Cascadilla Proceedings Project, 51-69.

Клајн и Шипка 2006: Клајн, И. и М. Шипка. (2006). Велики речник страних речи и израза. Нови Сад: Прометеј.

Лантолф 2000: Lantolf, J. P. (2000). Sociocultural theory and second language learning. Oxford: Oxford University Press.

Леви и Стоквел 2006: Levy, M. \& G. Stockwell. (2006). CALL dimensions: Options and issues in computer-assisted language learning. Mahawah, New Jersey: Lawrence Erlbaum Associates.

Ли 2008: Lee, L. (2008). Focus on form through collaborative scaffolding in expert to novice online interaction, Language Learning \& Technology, XII, 3, 53-72.

Љубојевић 2013: Љубојевић, Д. (2013). Конструктивистичка парадигма као нова теоријска основа за усвајање страних језика. У: Ј. Вучо, О. Дурбаба (прир.), Језик и образовање, Београд: Филолошки факултет, 27-44.

Маркес-Шефер 2013: Marques-Schäfer, G. (2013). Deutsch lernen online: Eine Analyse interkultureller Aktionen im Chat. Tübingen: Narr.

Милутиновић 2011: Милутиновић, J. (2011). Социјални конструктивизам у области образовања и учења, Зборник Института за педагошка истраживања, 43 (2), 177-194.

Мичел и Мајлс 2004: Mitchell, R. \& F. Myles. (2004). Second language learning theories. London: Arnold. 
Пешикан 2010: Pešikan, A. (2010). Savremeni pogled na prirodu školskog učenja i nastave: socio-konstruktivističko gledište i njegove praktične implikacije, Psihološka istraživanja, XIII, 2, 157-184.

Пијаже 1977: Pijaže, Ž. (1977). Psihologija inteligencije. Beograd: Nolit.

Радић-Бојанић 2012: Radić-Bojanić, B. (2012). Virtuelna kolaboracija među studentima. U: B. Radić-Bojanić (prir.), Virtuelna interakcija i kolaboracija u nastavi engleskog jezika i književnosti, Novi Sad: Filozofski fakultet, 21-34.

Ришоф и Волф 1999: Rüschoff, В. \& D. Wolff. (1999). Fremdsprachenlernen in der Wissensgesellschaft: zum Einsatz der Neuen Technologie in Schule und Unterricht. Ismaning: Max Hueber Verlag.

Свејн 2000: Swain, M. (2000). The output hypothesis and beyond. U: Lantolf, J. P. (prir.) Sociocultural theory and second language learning, Oxford: Oxford University Press, 97-114.

Стојнов 2005: Стојнов, Д. (2005). Од психологије личности ка психологији особа (Конструктивизам као нова платформа у образовању и васпитању). Београд: Институт за педагошка истраживања.

Фернандез-Гарсија и Мартинез-Арбелаиз 2002: Fernández-García, M. \& A. Martínez-Arbelaiz. (2002). Nonnative speaker-nonnative speaker synchronous discussions, CALICO Journal, XIX, 2, 279-294.

Шапел 2003: Chapelle, C. (2003). English language learning and technology: Lectures on teaching and research in the age of information and communication. Amsterdam: John Benjamins. 
Марина Ђукић Мирзајанц

\title{
Marina Đukić Mirzayantz
}

\section{EINIGE THEORETISCHE ANSÄTZE IM COMPUTERUNTERSTÜTZTEN FREMDSPRACHENUNTERRICHT}

\author{
Zusammenfassung
}

Kenntnisse und Anwendung von wissenschaftlichen Theoriensindder Schlüssel zur Verbesserung der Qualität des Fremdsprachenunterrichts. Das Ziel dieses Beitrags istdie wichtigsten Merkmale von Theorien zu zeigen, die die Lehrenden als Forscher am meisten heranziehen, wenn sie in ihrer Praxis eine Technologie verwenden. Aushandeln vonBedeutung und modifizierter Input sind die wichtigsten Themen der Interaktionshypothese. Soziokulturelle Theorie analysiert die Verknüpfung der Teilnehmer am Lernprozess. Für die Vertreter dieser theoretischen Richtung ist nur diejenige Interaktion wirksam,in der eseine asymmetrische Beziehung zwischen Partnern in Bezug auf ihre kognitiven Kompetenzen gibt. Als idealer Partner wird am häufigsten der Lehrende vorgeschlagen, daer Darsteller von Kenntnissen und Kulturwerten ist. Im Mittelpunkt des Interesses vom Konstruktivismus stehen individuelle und soziale Repräsentationen der Welt. Diese Theorie kritisiert das Bild des passiven Lernenden, der Schulinhalte auswendig lernt. Die Beziehung zwischendem Lehrenden und den Lernenden sowie unter den Lernenden ist keinesfallsuntergeordnetsondern kooperativ. Die Lernenden nehmen schrittweise die Verantwortung für ihr Lernen.

Wenn wir all dies beachten, drängt sich die Schlussfolgerung auf, das keine der oben erwähnten Theorien alle Probleme im Fremdsprachenunterricht gelöst hat. Die Vielfalttheoretischer Ansätze hilft dem Lehrenden, eine Methodezu entwickeln, die am wirksamsten für seine Lernenden ist. Der Einfluss von verschiedenen Ansätzen kann daran erkannt werden, auf welche Art und Weise er mitFehlern seiner Lernenden umgeht oderUnterrichtsaktivitäten erstellt.

Schlüsselwörter: Interaktionshypothese, soziokulturelle Theorie, Konstruktivismus, computerunterstützter Fremdsprachenunterricht (CALL)

Примљено 7. септембра 2016. године Прихваћено за објављивање 9. новембра 2016. године 